\title{
Correction to: Cubic bent functions outside the completed Maiorana-McFarland class
}

\author{
Alexandr A. Polujan ${ }^{1}(\mathbb{D}) \cdot$ Alexander Pott $^{1}$ \\ Published online: 20 April 2021 \\ (c) The Author(s) 2021

\section{Correction to: Des. Codes Cryptogr. https://doi.org/10.1007/s10623-019-00712-y}

The article "Cubic bent functions outside the completed Maiorana-McFarland class" written by Alexandr A. Polujan and Alexander Pott, was originally published Online First without Open Access. After publication in volume 88, issue 9, page 1701-1722, the author decided to opt for Open Choice and to make the article an Open Access publication. Therefore, the copyright of the article has been changed to (OThe Author(s) 2021 and the article is forthwith distributed under the terms of the Creative Commons Attribution 4.0 International License, which permits use, sharing, adaptation, distribution and reproduction in any medium or format, as long as you give appropriate credit to the original author(s) and the source, provide a link to the Creative Commons licence, and indicate if changes were made. The images or other third party material in this article are included in the article's Creative Commons licence, unless indicated otherwise in a credit line to the material. If material is not included in the article's Creative Commons licence and your intended use is not permitted by statutory regulation or exceeds the permitted use, you will need to obtain permission directly from the copyright holder. To view a copy of this licence, visit http://creativecommons.org/licenses/ by/4.0.

The original article has been corrected.

Open Access This article is licensed under a Creative Commons Attribution 4.0 International License, which permits use, sharing, adaptation, distribution and reproduction in any medium or format, as long as you give appropriate credit to the original author(s) and the source, provide a link to the Creative Commons licence, and indicate if changes were made. The images or other third party material in this article are included in the article's Creative Commons licence, unless indicated otherwise in a credit line to the material. If material is not included in the article's Creative Commons licence and your intended use is not permitted by statutory

The original article can be found online at https://doi.org/10.1007/s10623-019-00712-y.

$\bowtie \quad$ Alexandr A. Polujan

alexandr.polujan@gmail.com; alexandr.polujan@ovgu.de

Alexander Pott

alexander.pott@ovgu.de

1 Otto von Guericke University, Universitätsplatz 2, 39106 Magdeburg, Germany 
regulation or exceeds the permitted use, you will need to obtain permission directly from the copyright holder. To view a copy of this licence, visit http://creativecommons.org/licenses/by/4.0/.

Publisher's Note Springer Nature remains neutral with regard to jurisdictional claims in published maps and institutional affiliations. 